\title{
BOARD STRUCTURE AND SUPPLEMENTARY COMMENTARY ON THE PRIMARY FINANCIAL STATEMENTS
}

Tauringana, V. and Mangena, M.

\begin{abstract}
Purpose

This research investigates the relationship between the extent and focus of supplementary narrative commentary (SNC) on amounts reported in the primary financial statements and board structure variables.

\section{Design/Methodology/Approach}

The study uses the disclosure index methodology to measure the extent of SNC in annual reports of 167 FTSE 250 companies. Ordinary Least Squares (OLS) regression analysis is employed to examine the association between the extent and focus of SNC and board structure variables.
\end{abstract}

\section{Findings}

The findings show that the extent of SNC on amounts reported in the primary financial statements is about $30 \%$, suggesting that companies provide commentary on a small number of amounts reported in the financial statements. In terms of focus of SNC, companies provide greater SNC on amounts in the income statement relative to the balance sheet. The regression results indicate that the extent of SNC is negatively associated with board size, and positively associated with audit committee independence and financial expertise. Focus of SNC is negatively related to audit committee independence and finance expertise.

\section{Originality/Value}

The research contributes to both the voluntary disclosure and impression management literature streams. The findings provide evidence of the extent and focus of SNC on amounts in the financial statements. They also demonstrate that board structure variables are related to the extent and focus of SNC on amounts in primary financial statements. These findings have implications for policy makers who have responsibilities for ensuring that users of annual reports receive adequate information to make decisions.

Key words: board structure, supplementary narrative commentary; financial statements; voluntary disclosure; impression management.

Paper Type Research Paper 


\section{Introduction}

In this paper, we investigate supplementary narrative commentary (SNC) on amounts reported in the primary financial statements ${ }^{1}$ using a sample of UK listed companies. We take advantage of the delineation of narrative information into complementary and supplementary commentary by the ASB (2006) and International Accounting Standards Board (IASB, 2010). Making this distinction, the ASB (2006) notes, on the one hand, that complementary narrative information provides useful financial and nonfinancial information about the business and its performance that is not reported in the financial statements (emphasis added) but which, the directors judge, might be relevant to members' evaluation of past results and assessment of future prospects. On the other hand, supplementary narrative information provides additional explanations of amounts recorded in the financial statements (emphasis added) and explains the conditions and events that shaped the information. Both ASB (2006) and IASB (2010) suggest that supplementary narrative disclosures are an important dimension of the information set underpinning the decision-usefulness of financial statements. In addition, the Financial Reporting Review Panel (FRRP, 2010) also points to the usefulness of supplementary narrative commentary and emphasises the need to explain the key points in the company's performance and position, whether it is good or bad. Furthermore, the Companies Act 2006 requires companies to provide supplementary explanations on amounts reported in the primary financial statements to aid shareholders in their assessment of company performance and financial position.

Similarly, the academic literature also argues that SNC is important to investors as it provides a means of clarifying the financial statements numbers (Cole and Jones, 2005). Abarbanell and Bushee (1998) and Cole and Jones (2005) argue that explanations on changes to amounts reported in the primary financial statements 
compared to previous year provide market participants with better insights into whether the changes represent good or bad news. For example, an increase in debt might either be good news (Harris and Raviv, 1990) or bad news (Miller and Rock, 1985). To the extent that no supplementary commentary is provided on the increase in debt, investors would not know the reasons for such an increase. Other studies show that supplementary commentary affects share price returns (e.g., Kyeyune, 2010; Tauringana et al., 2011) and helps private unsophisticated users to understand the financial results better because it is couched in non-technical language (Bartlett and Chandler, 1997). ${ }^{2}$ In spite of this, in the UK, management has considerable discretion regarding supplementary commentary provision. The only requirement by the Companies Act 2006 (section 417) states that the business review must, "where appropriate, include references to, and additional explanations of, amounts included in the company's annual accounts' without further guidance on which or how many of the amounts should be commented on. This discretion provides an interesting setting to investigate because there are likely to be greater variations in commentary among companies.

There is much literature investigating disclosure in different media, and the impact of corporate governance and company-specific factors on such disclosures. For example, some studies have examined aggregate disclosure (e.g., Barako et al., 2006; Haniffa and Cooke, 2002). Others have focused on specific disclosure types such as management earnings forecasts (Karamanou and Vafeas, 2005); social information (Said et al., 2009); environmental information (Liu and Anbumozhi, 2008); and intellectual capital information ( $\mathrm{Li}$ et al., 2008). These studies provide important insights into disclosure practices and their relation with corporate governance factors, but 
the results are mixed and suggest that different types of disclosure may be influenced by different factors (see Barako, 2007).

Our study extends the literature by focusing on SNC, an important type of disclosure which is useful to the capital markets (ASB, 2006; Tauringana et al., 2011), but for which evidence is limited. Although the impression management studies examined supplementary commentary, they have focused mainly on revenues, profit and earnings per share (see Aerts, 1994; Clatworthy and Jones, 2003) so that there is no comprehensive evidence on SNC. Additionally, these studies have focused on examining the self-serving behaviour of managers in explaining performance. In this regard, our study has three objectives. First, we examine the extent to which UK companies provide SNC on amounts reported in the primary financial statements. Second, we analyse the extent to which there is SNC focus in the commentaries on the primary financial statements. We define SNC focus as the propensity to provide SNC on more amounts reported in one primary financial statement relative to the other. This is supported by the impression management literature (Abrahamson and Park, 1994; Clatworthy and Jones, 2003), which suggests that managers have incentives to use corporate reports to 'manipulate the perceptions and decisions of stakeholders' (Yuthas et al., 2002, p. 142). In this context, we argue that managers may focus their commentary on amounts in the financial statement that shows good performance, thus portraying themselves in good light. Finally, we examine whether differences in the extent and focus of SNC can be explained by differences in corporate governance mechanisms, in particular board structure variables. In this context, we investigate whether boards of directors take actions that increase SNC, but curtail SNC focus.

Our sample consists of 167 companies selected from the London Stock Exchange (LSE)'s FTSE 250 index. We measure SNC using the disclosure index 
methodology (e.g., Haniffa and Cooke, 2002; Mangena and Pike, 2005). We find that approximately $30 \%$ of the amounts are commented on. This implies that the absence of specific requirements by the Companies Act 2006 and/or guidance by the ASB (2006) means that users of annual reports may be denied useful information. In terms of SNC focus, we observe that companies comment more on income statement amounts relative to balance sheet amounts, suggesting that there is propensity to explain financial performance more than financial position. After controlling for company size, age, analyst following and industry, the regression results indicate a positive relation between the extent of SNC and audit committee independence and financial expertise, but negative relation with board size. We find no significant relationship between SNC and the proportion of non-executive directors. Our results show that SNC focus is negatively related to audit committee independence and financial expertise, but has no significant relation with board size and proportion of non-executive directors. Overall, these results are consistent with previous research suggesting effective boards improve the quality of financial reporting (e.g., Mangena and Pike, 2005; Karamanou and Vafeas, 2005).

Our study contributes to the literature in a number of ways. First, we provide the first time evidence on the extent and focus of SNC on amounts reported in the primary financial statements. Second, we contribute to the literature by providing evidence on the relationship between the extent and focus of SNC and board structure variables. These issues have not been addressed in prior literature.

The rest of the paper is organised as follows. In Section 2, we summarise the literature and develop the hypotheses in Section 3. We discuss the research methods in Section 4, and in Section 5, we present and discuss the empirical findings. The final section is a summary and conclusion. 


\section{Literature Review}

Barton and Mercer (2005) suggest that SNC is an important element of a company's disclosure policy. There are many reasons why managers might want to provide supplementary narrative commentary. Merkl-Davies and Brennan (2007) group the reasons into two perspectives. One perspective is that SNC overcomes information asymmetries between managers and outsiders (Healy and Palepu, 2001; Merkl-Davies and Brennan, 2007). Information asymmetry arises from the separation of ownership from control in companies (Jensen and Meckling, 1976), which increases agency costs (Healy and Palepu, 2001). Diamond and Verrecchia (1991) suggest that enhanced disclosure reduces information asymmetry. In this context, the provision of SNC can be seen as an attempt by managers to reduce information asymmetry, and helping improve investor understanding of the results, thus increasing the liquidity of the shares and lowering the cost of financing (Barton and Mercer, 2005).

The second perspective is that managers have incentives to provide supplementary commentary to exploit the information asymmetries and engage in impression management (Clatworthy and Jones, 2003; Barton and Mercer, 2005). Impression management refers to the process by which individuals attempt to control the impression of others (Merkl-Davies and Brennan, 2007). In corporate reporting, impression management occurs when management selects information to display and presents the information in a manner that distorts readers' perceptions of corporate achievements (Merkl-Davies and Brennan, 2007). This implies that management behave opportunistically and provide self-serving information to enhance the capital market perceptions of their abilities and company's prospects (e.g., Clatworthy and Jones, 
2003). In the context of SNC, managers may have a propensity to provide more SNC on amounts in the financial statement that show them in good light.

\section{Hypotheses development}

The board of directors is responsible for monitoring managerial performance in general (Karamanou and Vafeas, 2005), and in particular, the financial reporting processes (Mangena and Pike, 2005). In the context of financial reporting, the UK Corporate Governance Code (FRC, 2012, p. 17) points that the board of directors has the 'responsibility to present a fair, balanced and understandable assessment of the company's position and prospects'. Similarly, the Companies Act 2006 (section 417) also requires that in the business review, the board should provide a balanced and comprehensive analysis of financial performance and position of the company. Aerts and Tarca (2010) argue that the provision of supplementary explanations is a key component of board accountability, suggesting that the balanced and comprehensive analysis should include SNC. As Coles and Jones (2005) point out, SNC on amounts reported in the financial statements aids investors to gain a better understanding of both financial performance and financial position of the company. Schaffer (2002) and Barton and Mercer (2005) also suggest that SNC can help the board of directors in their monitoring and evaluation of managerial performance. For example, the board might use them to assess managerial performance compared to previous year as well as monitor or judge achievement of objectives set out. Consequently, we argue that effective board structures (i.e., board size, non-executive directors and audit committees) will enhance the extent of SNC and reduce the extent of SNC focus. 


\subsection{Board size}

The link between board size and disclosure has been investigated by only a few studies (e.g. Cheng and Courtenay, 2006; Said et al., 2009). The argument is that larger boards are more likely to be endowed with a greater range of expertise, thus enhance effective monitoring of management actions (Karamanou and Vafeas, 2005). In contrast, the benefits of large boards may be offset by the incremental cost of poorer communication and decision making inefficiencies that are associated with large groups (Dalton et al., 1999). This means that with dispersed opinions and noncohesiveness in viewpoints, boards that are too large may actually have diminished monitoring capabilities (Cheng and Courtenay, 2006). These contrasting views suggest that the effects of board size on the extent and focus of SNC are not clear. However, the limited empirical evidence suggests that there is no significant relation between board size and voluntary disclosure (see Karamanou and Vafeas, 2005; Said et al., 2009). Nevertheless, given the contrasting views, we make no directional prediction on the relation between board size and SNC. Thus:

H1: There is an association between board size and the extent of SNC on amounts reported in the primary financial statements.

H2: There is an association between board size and the extent of SNC focus on amounts reported in the primary financial statements.

\subsection{Proportion of Non-executive Directors}

A number of studies have linked the proportion of non-executive directors (NEDs) to disclosure (e.g., Eng and Mak, 2003; Mangena and Tauringana, 2007) and management earnings forecasts (e.g., Ajinkya et al., 2005; Karamanou and Vafeas, 2005). These studies suggest that NEDs have incentives to protect shareholder 
interests against managerial opportunism. In this respect, we suggest that NEDs may take actions that encourage more SNC on amounts in the primary financial statements (1) to comply with the requirements of the Companies Act 2006 and the recommendations of the ASB (2006) and (2) to aid their assessment of managerial performance (Schaffer, 2002; Barton and Mercer, 2005). In addition, given their responsibility to provide a balanced assessment of the financial performance and position, NEDs are more likely to discourage SNC focus.

Empirically, some studies support a positive relation with disclosures (see Karamanou and Vafeas, 2005; Ajinkya et al., 2005). Others show no significant relation with interim disclosures and statements of best practice (e.g., Mangena and Pike, 2005; Mangena and Tauringana, 2007). Nevertheless, we hypothesise the following:

H3: $\quad$ There is a positive association between the proportion of non-executive directors and the extent of SNC on amounts reported in the primary financial statements

H4: There is a negative association between the proportion of non-executive directors and the extent of SNC focus on amounts reported in the primary financial statements.

\subsection{Audit Committee}

The board of directors performs its monitoring activities by delegating important oversight duties to relevant board committees (Mangena and Pike, 2005; Karamanou and Vafeas, 2005). In terms of financial reporting, the audit committee (AC) has the delegated responsibility to ensure the quality of the financial reporting processes (Smith Committee, 2003; Mangena and Pike, 2005). The Smith Committee (2003) suggests that the effectiveness of the $\mathrm{AC}$ is enhanced when the $\mathrm{AC}$ is independent and 
has financial expertise. The issue of $\mathrm{AC}$ independence draws from the widely accepted notion that independent directors are more likely to be effective monitors of management actions (e.g., Fama and Jensen, 1983). Carcello and Neal (2003) argue that an independent $\mathrm{AC}$ is more likely to be free from management influence in ensuring the quality and credibility of the financial reporting process. Given the importance of SNC to capital market participants (see ASB, 2006; IASB, 2010), we suggest that an independent $\mathrm{AC}$ would enhance the provision of this type of information and reduce the level of SNC focus. Empirical evidence shows a positive relationship between AC independence and disclosure (Mangena and Pike, 2005; Mangena and Tauringana, 2007) and management earnings forecasts (Karamanou and Vafeas, 2005; Ajinkya et al., 2005). Thus we hypothesise:

Hs: $\quad$ There is a positive association between audit committee independence and the extent of SNC on amounts reported in the primary financial statements

H6: $\quad$ There is a negative association between audit committee independence and the extent of SNC focus on amounts reported in the primary financial statements.

The UK Corporate Governance Code (FRC, 2012) recommends the AC should comprise members with knowledge of the business environment, and, at least one AC member should have recent and relevant financial experience. Knowledgeable AC members are in a better position to understand (1) the capital market implications of providing quality disclosures (Karamanou and Vafeas, 2005; Mangena and Pike, 2005) and (2) the implications of compliance with regulatory requirements and best reporting practices (Mangena and Tauringana, 2007). This should lead to improvement in disclosure, including the provision of $\mathrm{SNC}$ in the financial statements. Prior empirical studies indicate a negative relation between financial 
expertise and financial statements fraud (e.g., Abbott et al., 2000), earnings management (Klein, 2002); dismissal of auditors after issuing a going concern report (Carcello and Neal, 2003), and a positive relationship with disclosure (Mangena and Tauringana, 2007). Hence:

H7: $\quad$ There is a positive association between AC finance expertise and the extent of SNC on amounts reported in the primary financial statements

Hs: $\quad$ There is a negative association between AC financial expertise and the extent of SNC focus on amounts reported in the primary financial statements.

\section{Research Methods}

\subsection{Model specification}

To examine the association between the board structure variables and the extent and focus of SNC in the primary financial statements, we specify the following two multiple regression models:

$$
\begin{array}{r}
S N C=\quad \begin{array}{r}
\beta_{0}+\beta_{1} B D S Z+\beta_{2} N E D S+\beta_{3} A C I N+\beta_{4} A C F E+\beta_{5} C O S Z+\beta_{6} A N F G \\
+\beta_{7} G E A R+\beta_{8} P R F T+\beta_{9} L Q D T+\beta_{10} C O A G+\varepsilon_{j}
\end{array} \\
\text { SNC FOCUS }=\quad \beta_{0}+\beta_{1} B D S Z+\beta_{2} N E D S+\beta_{3} A C I N+\beta_{4} A C F E+\beta_{5} C O S Z+ \\
\beta_{6} A N F G+\beta_{7} G E A R+\beta_{8} P R F T+\beta_{9} L Q D T+\beta_{10} C O A G+\varepsilon_{j}
\end{array}
$$

We define all the variables in Table I. Drawing from prior research, we control for a number of other variables that are linked to disclosure. These are company size (Haniffa and Cooke, 2002); analyst following (Hope, 2003); gearing (Schwartz and 
Soo, 1996); profitability and liquidity (Barako, 2007) and company age (Li et al., 2008)

\section{INSERT TABLE I ABOUT HERE}

\subsection{Data and Sample selection}

We collected data for our analyses from three sources. SNC measures and all board structure and control variables, except for analyst following and company age, were collected from the annual reports published during the year 2007. For analyst following and company age, we collected data from ShareScope and LSE, respectively. Our sample was drawn from the LSE, in particular all the non-financial FTSE 250 companies listed as at 31 December 2007. The FTSE 250 companies are likely to be more widely owned, thus exhibiting greater separation of ownership and control (Karamanou and Vafeas, 2005). In these companies, voluntary disclosures are likely to be more critical in reducing information asymmetries between management and shareholders. Consistent with previous research (e.g., Mangena and Tauringana, 2007), we eliminated 77 financial companies (such as banks, insurance) because they face additional disclosure and corporate governance requirements, which may not be faced by non-financial companies. We then downloaded annual reports for the 173 remaining companies from the individual companies' websites. Following this, we eliminated two companies that were taken over and three that changed their accounting period during the period covered by our study. We expect these events to trigger the provision of more SNC to explain their effects on the amounts in the primary financial statements. We further eliminated one more company because it has negative equity and we considered it to be an outlier. The final sample used in this study is 167 companies. 


\subsection{Measuring supplementary narrative commentary}

We measure the extent of SNC using a disclosure index methodology (e.g., Haniffa and Cooke, 2002; Owusu-Ansah, 2005). We first developed a checklist of all the items required to be disclosed on the face of the primary financial statements from an analysis of the requirements of UK and international accounting standards. ${ }^{3}$ This process yielded a total of 44 items, as indicated in Table II.

\section{INSERT TABLE II ABOUT HERE}

To measure the extent of SNC, a company is awarded a score of ' 1 ' for the presence of SNC on the relevant amounts, and '0' otherwise. In identifying the SNC, we read the narrative section of the annual report. Unlike previous studies, the issue of item applicability is not a problem in our study because SNC relates to specific amounts in the primary financial statements. For example, if the item, 'finance costs', is included in the income statement, then the expectation is that it should be commented on and hence applicable to the company. This means that if a narrative commentary is not provided, the company is awarded a ' 0 ' score. On the other hand if the item, 'finance costs', is not included in the income statement, then the item is considered not applicable and scored accordingly. After scoring all the items, the SNC score for each company is computed as an index by dividing the company's total score (i.e., the sum of all the 1's) by the maximum possible score for the company. For each company, we create four SNC indices: overall SNC index, income statement SNC index, balance sheet SNC index and the SNC focus index (see Table I for definitions). ${ }^{4}$ The scoring of all annual reports was conducted by one well-experienced coder. However, a 
second coder randomly selected $10 \%$ of the sample (17 annual reports) and independently scored the reports. The correlation coefficient between the scores of the two coders was 0.99 , suggesting that the scores are reliable.

\section{Empirical Findings}

\subsection{Descriptive statistics}

The summary descriptive statistics for SNC, board and control variables are presented in Table III. In terms of SNC, we provide descriptive statistics for the overall as well as for the two individual primary financial statements: income statement and balance sheet. The mean level of overall SNC on amounts in the primary financial statements is $30.2 \%$. These results suggest that companies provide SNC on a small number of amounts in the primary financial statements. This, perhaps, reflects the loose Companies Act 2006 section 417(8) requirements, that leave decisions to management discretion. As noted earlier, the Act does not specify how many items or which amounts in the primary financial statements companies are required to provide supplementary commentary on.

With regard to the individual primary financial statements, Table III shows that companies provide more $\mathrm{SNC}$ on amounts in the income statement relative to the balance sheet. The mean SNC in the income statement is $42.3 \%$ compared to $20.1 \%$ in the balance sheet. These results are also reflected in our SNC focus measure with a mean of 2.659 , reflecting the propensity by managers to explain more income statement amounts relative to balance sheet amounts. This suggests that companies may not be providing a balanced assessment of financial performance and financial position. There are two possible explanations for this focus. One, from the perspective of the impression management literature, management might be commenting on income statement amounts 
because performance is good, and wants to portray themselves in good light (Clatworthy and Jones, 2003). Alternatively, managers know that the most read financial statement by both analysts and individual investors alike is the income statement (e.g. Bartlett and Chandler, 1997; Black and White, 2003) and therefore are responding to this need for information

\section{INSERT TABLE III ABOUT HERE}

Table III also presents summary statistics for the board structure and control variables. The mean board size consists of about nine directors and the mean proportion of nonexecutive directors is $56 \%$. The results also show that on average $81 \%$ of AC members are independent and $38 \%$ have financial expertise. The percentage of AC members with financial expertise is slightly higher than the $30 \%$ reported by Mangena and Tauringana (2007) (using data collected in the 2002 interim reports), suggesting the number of AC members with financial expertise has increased over time. As for the control variables, the mean company size (market capitalisation) is $£ 1,048.9$ million and the mean number of analysts is five. The means for the other variables are as follows: gearing ratio (1.07), average profitability (15.4\%), liquidity ratio (1.58) and company age (21 years).

\subsection{Regression results and discussion}

In Table IV, we provide the Pearson product-moment correlation matrix among the independent variables.

INSERT TABLE IV ABOUT HERE 
An examination of the correlations among our independent variables suggests no multicollinearity problems exist. Field (2005) suggests that multicollinearity becomes a problem only when the correlations exceed 0.80 or 0.90 . As Table IV shows, all the correlations are below these threshold values. We also examine the variance inflation factors (VIFs) (not tabulated) to further test for multicollinearity and all are well below the threshold value of 10 (see Field, 2005).

In Table V, we present the results of the four multiple regression models. ${ }^{5}$ Our data-set is not normally distributed, and therefore we run these regressions using normal scores (Cooke, 1998). Column 2 of Table V presents the model results of the relation between board structure variables and the overall SNC index. Columns 3 and 4 present the model results of the relation between the board structure variables and the SNC measures in the individual primary financial statements, that is, the income statement and balance sheet, respectively. Finally, in column 5, we present the results of the relation between SNC focus and the board structure variables. Our results indicate that all four models have significant explanatory power. The Adjusted $\mathrm{R}^{2}$ ranges from $17.2 \%$ for the income statement index to $29.2 \%$ for the overall SNC index. The Adjusted $\mathrm{R}^{2}$ of $25.0 \%$ for the balance sheet (column 4) suggests that our model explains variations in the balance sheet supplementary commentary better than it does for variations in the income statement (with adjusted $\mathrm{R}^{2}$ of $17.2 \%$ ). The Fratios for all the models are significant.

\section{INSERT TABLE V ABOUT HERE}

We first focus on the extent of SNC (columns 2 to 4). With regard to the overall SNC (Column 2), the results in Table V show that board size, AC independence and 
finance expertise are associated with $\mathrm{SNC}$ at the 5\% level or better. Thus our hypotheses $1\left(\mathrm{H}_{1}\right), 5\left(\mathrm{H}_{5}\right)$ and $7\left(\mathrm{H}_{7}\right)$ are supported. The coefficient of proportion of non-executive directors is, however, not significant, hence hypothesis $3\left(\mathrm{H}_{3}\right)$ is not supported. In terms of the individual primary financial statements, we find that AC independence and financial expertise are positively associated with commentary in both the income statement (Column 3) and the balance sheet (Column 4) at the 5\% level or better. The coefficients of board size and proportion of non-executive directors are not significant. Taken overall, our results suggest that companies with effective board structures provide SNC on more amounts in the primary financial statements.

The findings of a negative association between board size and the extent of SNC contradict Cheng and Courtenay (2006) and Said et al. (2009) who report no significant association. Nevertheless, our results support the argument that larger boards are not effective monitors of management (Dalton et al., 1999), and may not enforce high level of commentary on amounts in the primary financial statements. Our results indicating that $\mathrm{AC}$ independence and financial expertise are positively associated with SNC are consistent with previous studies (e.g., Kelton and Yang, 2008). This implies that AC independence and expertise are important in ensuring transparency and improve monitoring of financial reporting (Carcello and Neal, 2003). Additionally, the results support the recommendations contained in the UK Corporate Governance Code (FRC, 2012) that ACs should be composed of independent non-executive directors and members with financial expertise.

For the control variables, we find that company size is related to overall, income statement and balance sheet SNC consistent with previous studies (e.g. Mangena and Pike, 2005; Li et al., 2008). Analyst following is not related to overall supplementary 
commentary, but is negatively related to the balance sheet statement and positively related to income statement supplementary commentary. Gearing ratio and company age are related to balance sheet supplementary commentary at the $10 \%$ level or better and $1 \%$ level or better, respectively. We find no significant relation with profitability and liquidity.

Finally, in respect of SNC focus (Column 5), we find that the coefficients of AC independence and financial expertise are negative and significant at the 5\% level or better. Hence, our hypotheses $6\left(\mathrm{H}_{6}\right)$ and $8\left(\mathrm{H}_{8}\right)$ are supported. However, both board size and proportion of non-executive directors are not significantly related to SNC focus, thus hypothesis $2\left(\mathrm{H}_{2}\right)$ and $4\left(\mathrm{H}_{4}\right)$ are not supported. These results are interesting and suggest that when the $\mathrm{AC}$ is independent and has financial expertise, the propensity for managers to provide commentary on more amounts in the income statement relative to balance sheet amounts may be curtailed. In this case, the results suggest that the presence of AC members who are independent and with financial expertise might result in a balanced commentary on amounts in the primary financial statement. In terms of the control variables, $\mathrm{SNC}$ focus is negatively related to company size and company age at the $5 \%$ and $1 \%$ level or better, respectively. The relation between analyst following and supplementary narrative focus is positive at the $1 \%$ level or better, implying that companies with large analysts following provide more commentary on amounts in the income statement. This perhaps reflects the attempt by management to provide information to meet the demands of analysts (see Barker, 1998; Mangena et al., 2007). Overall, these results suggest that the propensity to provide SNC on more income statement amounts relative to balance sheet amounts is lower in companies that (1) have effective AC structures, (2) are large, and (3) have 
a long history of stock exchange listing, but higher in companies with greater analyst following.

\section{Summary and Conclusion}

The focus of this study was to investigate the extent and focus of SNC on the amounts reported in the primary financial statements in the annual reports. We also investigated the relation between the extent and focus of SNC and board structure variables, in particular board size, proportion of non-executive directors, audit committee independence and financial expertise. We find that companies provide SNC on a small number of amounts in the primary financial statements. Our results show that companies are more inclined to provide $\mathrm{SNC}$ on amounts reported in the income statement relative to the balance sheet amounts, raising doubts about whether companies provide a balanced assessment of company performance and position. We find that SNC is negatively related to board size, but positively related to AC independence and financial expertise. We also find that $\mathrm{AC}$ independence and financial expertise are negatively related to SNC focus, suggesting that effective audit committees may encourage a more balanced supplementary commentary.

These results should be interpreted in the light of the fact that our model has explained only a very small amount of the variation in the extent and focus of SNC. Also while the use of SNC mitigates the problem of item applicability associated with previous disclosure studies, the limitation of our approach is that we assume that companies have to provide commentary on all amounts in the primary financial statements. It is possible that an amount in the financial statements has remained largely unchanged, and with no material changes, managers might perhaps find little need to comment. Further, the study examined the extent and focus of supplementary 
narrative commentary using annual reports only. Potentially, some of the changes to amounts in the financial statements may have been explained through other media.

In spite of these limitations, our study makes some important contributions to disclosure literature. First, the study provides the first evidence on the extent and focus of SNC on amounts in the primary financial statement. To the best of our knowledge, there is no existing study that specifically examines supplementary narrative commentary as defined by the ASB (2006). The findings on SNC focus are new as no study has examined this issue before. These results contribute to the impression management literature in a different setting. Second, we also contribute to existing literature by providing evidence of the extent to which UK companies are responding to the requirements of the Companies Act 2006 and recommendation by ASB (2006) to provide SNC. The findings that companies provide supplementary commentary on a small number of the amounts reported in the primary financial statements suggest that companies can do more to inform investors in terms of the reason for changes to the amounts. We suggest that further guidance might be needed on which amounts to provide comment on in order to improve disclosure. Third, the finding of a relation between SNC and board size, AC independence and financial expertise contributes have implications for corporate governance policy makers.

\section{Notes}

${ }^{1}$ ASB (1999), Chapter 7, identifies primary financial statements as the income statement, the statement of recognised gains and losses, balance sheet and cash flow statement.

${ }^{2}$ Unlike sophisticated investors such as analysts and institutional investors, who have access to management (see Holland, 1998), unsophisticated investors have no access to management to ask for explanations of changes to amounts in the primary financial statements. Hence they rely on supplementary commentary given in the annual report to appreciate the reasons for changes in company financial position and performance. ${ }^{3}$ Although UK FTSE250 companies adopted IFRS on 1 January 2005, they continued to prepare a statement of recognised gains and losses. This was in line with the ASB (1999) Statement of Principles for Financial Reporting. For the period covered by the study, 
there were no requirements by IAS to prepare a statement of gains and losses. However, effective January 2009, IAS 1 (revised) requires a statement of comprehensive income.

${ }^{4}$ In our analyses, we incorporated the items in the statement of recognised gains and losses into the income statement and those in the cash flow statement into the balance sheet. Our reason for this is that the number of items in each of these statements is very small.

${ }^{5} \mathrm{We}$ re-run these regressions including industry dummies following Mangena and Tauringana (2007) and our results remain similar.

\section{References}

Abarbanell, J. and Bushee, B. (1998), "Abnormal returns to a fundamental analysis strategy", The Accounting Review, Vol. 73 No. 1, pp. 19-45.

Abbott, L.J., Park, Y. and Parker, S. (2000), "The effects of audit committee activity and independence on corporate fraud", Managerial Finance, Vol. 26 No 11, pp. 55-67.

Abrahamson, E. and Park, C. (1994), "Concealment of negative organizational outcomes: an agency theory perspective", Academy of Management Journal, Vol. 37 No. 5, pp. 1302-1334.

Accounting Standards Board. (1999), Statement of Principles for Financial Reporting, London: ASB.

Accounting Standards Board. (2006), Reporting Statement (RS) 1 - Operating and Financial Review, London: ASB.

Aerts, W. (1994), "On the use of accounting logic as an explanatory category in narrative accounting disclosures", Accounting, Organizations and Society, Vol. 19 No. 4/5, pp. 337-53.

Aerts, W. And Tarca, A. (2010), "Financial performance explanations and institutional setting", Accounting and Business Research, Vol. 40 No. 5, pp. 421-450.

Ajinkya, B., Bhojraj, S. and Sengupta, P. (2005), "The association between outside directors, institutional investors and the properties of management earnings forecasts", Journal of Accounting Research, Vol. 43 No. 3, pp. 343-376.

Barako, D.G. (2007), "Determinants of voluntary disclosures in Kenyan companies annual reports", African Journal of Business Management, Vol. 1 No. 15, pp. 113-128.

Barako, D.G., Hancock, P. and Izan, H.Y. (2006), "Factors influencing voluntary corporate disclosure by Kenyan companies", Corporate Governance: International Review, Vol.14 No. 2, pp. 107-125.

Barker, R.G. (1998), "The market for information-evidence from finance directors, analysts and fund managers", Accounting and Business Research, Vol. 29 No. 1, pp. 3-20.

Bartlett, S.A. and Chandler, R.A. (1997), "The corporate report and the private shareholder: Lee and Tweedie twenty years on", British Accounting Review, Vol. 29, pp. 245-261.

Barton J. And Mercer, M. (2005), "To blame or not to blame: analysts' reactions to external explanations for poor financial performance", Journal of Accounting and Economics, Vol. 39, pp. 509-533.

Black, E.L. and White, J.J. (2003), "An international comparison of income statement and balance sheet information: Germany, Japan and the US", European Accounting Review, Vol. 12, No. 1, pp. 29-46. 
Carcello, J.V. and Neal, T. L. (2003), "Audit committee independence and disclosure: choice for financially distressed firms", Corporate Governance: An International Review, Vol. 11 No. 4, pp. 289-299.

Cheng, E.C.M. and Courtenay, S.M. (2006), "Board composition, regulatory regime and voluntary disclosure", International Journal of Accounting, Vol. 41, pp. 262-289.

Clatworthy, M.A. and Jones, M.J. (2003), "Financial reporting of good news and bad news: evidence from accounting narratives", Accounting and Business Research, Vol. 33 No. 3, pp. 171-185.

Cole, C.J. and Jones, C.L. (2005), "Management discussion and analysis: a review and implications for future research", Journal of Accounting Literature, Vol. 24, pp. 135-174.

Cooke, T.E. (1998), "Regression analysis in accounting disclosure studies", Accounting and Business Research, Vol. 28 No. 3, p: 209-224.

Companies Act 2006. Chapter 46. London: Office of Public Sector Information.

Dalton, D.R., Daily, C.M., Johnson, J.L. and Ellstrand, A.E. (1999), "Number of directors and financial performance: a meta-analysis", Academy of Management Journal, Vol. 42 No.6, pp. 674-686.

Diamond, D.W. and Verrecchia, R.E. (1991), "Disclosure, liquidity, and cost of capital", Journal of Finance, Vol. 46 No.4, pp. 1325-1359.

Eng, L.L. and Mak, Y.T. (2003) , "Corporate governance and voluntary disclosure", Journal of Accounting and Public Policy, Vol. 22, pp. 325-45.

Fama, E. and M. Jensen (1983), "Separation of ownership and control", Journal of Law and Economics, Vol. 26, pp. 301-325.

Field, A. (2005) Discovering Statistic Using SPSS for Windows, $2^{\text {nd }}$ Edition, London: Sage.

FRC (2012). The UK Corporate Governance Code, London, FRC.

Haniffa, R.M. and Cooke, T.E. (2002), "Culture, corporate governance and disclosure in Malaysian corporations", Abacus, Vol. 38 No. 3, pp. 317-349.

Harris, M and Raviv, A (1990), "Capital structure and the information role of debt", Journal of Finance, Vol. 45, pp. 321-349.

Healy, P.M. and Palepu, K.G. (2001), "Information asymmetry, corporate disclosure, and the capital markets: a review of the empirical disclosure literature", Journal of Accounting and Economics, Vol. 31 Nos.1-3, pp. 405-440.

Holland, J.B. (1998), "Private disclosure and financial reporting", Accounting and Business Research, Vol. 28 No. 4, pp. 255-269.

Hope, O. (2003), "Analysts following and the influence of disclosure components, IPOs and ownership concentration", http://papers.ssrn.com/sol3/papers.cfm?abstract id=395800, accessed 8/09/09.

International Accounting Standards Board (2010), IFRS Practice StatementManagement Commentary, A framework for presentation. London, IASB.

Jensen, M.C. and Meckling, W.H. (1976), "Theory of a Firm: Managerial Behaviour, Agency Costs and Ownership Structure", Journal of Financial Economics, Vol. 3 No. 1, pp. 305-60.

Karamanou, I. and Vafeas, N. (2005), "The association between corporate boards, audit committees, and management earnings forecasts: An empirical analysis", Journal of Accounting Research, Vol. 43 No. 3, pp. 453-486.

Kelton, A.S and Yang, Y. (2008), "The impact of corporate governance on internet financial reporting", Journal of Accounting and Public Policy, Vol .27, pp. 6287. 
Klein, A (2002), "Audit committee, board of directors characteristics and earnings management", Journal of Accounting and Economics, Vol. 33 No. 3, pp. 375400.

Kyeyune, M. F. (2010), The Relative information content of complementary and supplementary narrative commentary in $U K$ interim reports, $\mathrm{PhD}$ Thesis, Bournemouth University.

Li, J., Pike, R. and Haniffa, R. (2008), "Intellectual capital disclosure and corporate governance structure in UK firms", Accounting and Business Research, Vol. 38 No. 2, pp. 137-159.

Liu, X and Anbumozhi, V. (2008), "Determinant factors of corporate environment information disclosure: An empirical study of Chinese listed companies", Journal of Cleaner Production, Vol. 30, pp 1-8.

Mangena, M. and Pike, R. (2005), "The effect of audit committee shareholding, financial expertise and size on interim financial disclosures", Accounting and Business Research, Vol. 35 No. 4, pp. 107-130.

Mangena, M. and Tauringana, V. (2007), "Corporate compliance with non-mandatory statements of best practice: the case of the ASB statement on interim reports", European Accounting Review, Vol. 16 No.2, pp. 1-29.

Merkl-Davies, D.M. and Brennan, N.M. (2007), "Discretionary disclosure strategies in corporate narratives: Incremental information or impression management", Journal of Accounting Literature, Vol. 26, pp. 116-194.

Miller, M.H. and Rock, K. (1985), "Dividend policy and asymmetric information, Journal of Finance, Vol. 40 No. 4, pp.1031-1051.

Owusu-Ansah, S. (2005), "Factors influencing corporate compliance with financial reporting requirements in New Zealand", International Journal of Commerce \& Management, Vol. 15 No. 2, pp. 141-157.

Said, R., Zainuddin, Y.J. and Haron, H. (2009), "The relationship between corporate social responsibility disclosure and corporate governance characteristics in Malaysian public listed companies”, Social Responsibility Journal, Vol. 5 No. 2, pp. 221-226.

Schaffer, B.S. (2002), "Board assessment of managerial performance: an analysis of attribution processes", Journal of Managerial Psychology, Vol.17 No. 2, pp. 95115.

Schwartz, K.B. and Soo, B.S. (1996), "Evidence of regulatory noncompliance with SEC disclosure rules on auditor changes", Accounting Review, Vol. 71 No. 4, pp. 555-572.

Smith Committee (2003), Audit Committees Combined Code Guidance, A report and proposed guidance by the FRC - appointed group. London: FRC.

Tauringana, V. Kyeyune, M.F and Hardwick, P. (2011) Information content of supplementary narrative commentaries in UK interim report, A paper presented to the American Accounting Association, International Section, Mid-year conference, Florida, USA.

Yuthas, K., Rogers, R. and Dillard, J.F. (2002), "Communicative action and corporate annual reports", Journal of Business Ethics, Vol. 41 Nos. 1-2, pp. 141-157. 


\begin{tabular}{|c|c|c|}
\hline & Variable(s) & Definition \\
\hline \multicolumn{3}{|c|}{ Supplementary Commentary Measures } \\
\hline $\mathrm{SNC}$ & $\begin{array}{l}\text { Overall supplementary } \\
\text { narrative commentary }\end{array}$ & $\begin{array}{l}\text { Supplementary narrative commentary on amounts in the primary } \\
\text { financial statements measured as an index computed by dividing } \\
\text { the total number of amounts (items) on which a commentary is } \\
\text { provided by the company scaled by the total possible number of } \\
\text { amounts (items) applicable to a particular company. }\end{array}$ \\
\hline $\begin{array}{l}\text { SNC } \\
\text { FOCUS }\end{array}$ & $\begin{array}{l}\text { Supplementary narrative } \\
\text { commentary focus }\end{array}$ & $\begin{array}{l}\text { Defined as the propensity to provide supplementary narrative } \\
\text { commentary more on amounts in one primary financial statement than } \\
\text { the other, and is measured as the income statement supplementary } \\
\text { narrative commentary score scaled by the balance sheet } \\
\text { supplementary narrative commentary score for the company. }\end{array}$ \\
\hline \multicolumn{3}{|c|}{ Corporate Governance Variables } \\
\hline BDSZ & Board size & $\begin{array}{l}\text { Board size is measured by the total number of directors on the } \\
\text { board as at the end of the year. }\end{array}$ \\
\hline NEDS & $\begin{array}{l}\text { Proportion of non-executive } \\
\text { directors }\end{array}$ & $\begin{array}{l}\text { Proportion of non-executive directors is measured by the number of } \\
\text { non-executive directors on the board scaled by total number of } \\
\text { directors on the board (as a percentage). We do not distinguish } \\
\text { between independent and non-independent non-executive directors. }\end{array}$ \\
\hline ACIN & AC independence & $\begin{array}{l}\text { Audit committee independence is measured by the number of } \\
\text { independent non-executive directors on the audit committee scaled } \\
\text { by the total number of directors on the audit committee (as a } \\
\text { percentage) }\end{array}$ \\
\hline ACFE & AC financial expertise & $\begin{array}{l}\text { Audit committee financial expertise is measured by the proportion } \\
\text { of the members of the audit committee who are identified as having } \\
\text { financial expertise scaled by the total number of directors on the } \\
\text { audit committee (as a percentage). We consider audit committee } \\
\text { members to have financial expertise if they hold an accounting or } \\
\text { finance qualification. }\end{array}$ \\
\hline \multicolumn{3}{|c|}{ Control Variables } \\
\hline COSZ & Company Size & $\begin{array}{l}\text { The market capitalisation of the company at the financial year end. } \\
\text { Market capitalisation is computed by multiplying the outstanding } \\
\text { ordinary shares by the market share price at the balance sheet date. }\end{array}$ \\
\hline ANFG & Analyst following & $\begin{array}{l}\text { Analysts' following is measured by the number of analysts issuing } \\
\text { EPS forecasts for the company as at balance sheet date. Data is } \\
\text { collected from ShareScope }\end{array}$ \\
\hline GEAR & Gearing & $\begin{array}{l}\text { Gearing ratio is measured as non-current liabilities at the end of the } \\
\text { financial year scaled by book value of equity at that date. }\end{array}$ \\
\hline PRFT & Profitability & $\begin{array}{l}\text { Profitability is measured by profit before interest and tax scaled by } \\
\text { capital employed }\end{array}$ \\
\hline LQDT & Liquidity & Liquidity is measured by current assets scaled by current liabilities \\
\hline COAG & Company age & $\begin{array}{l}\text { Company age is measured by the number of years the company has } \\
\text { been listed on the London Stock Exchange as at balance sheet date. }\end{array}$ \\
\hline
\end{tabular}




\begin{tabular}{|c|c|}
\hline \multicolumn{2}{|c|}{$\begin{array}{l}\text { Table II: Supplementary narrative commentary items } \\
\text { Income statement }\end{array}$} \\
\hline 1 & Revenue from continuing operations \\
\hline 2 & Cost of sales from continuing operations \\
\hline 3 & Gross profit from continuing operations \\
\hline 4 & Other Income, e.g. profit from sale of plant and equipment \\
\hline 5 & Operating costs - administrative and selling \\
\hline 6 & Other Expense - e.g. loss from sale of plant and equipment \\
\hline 7 & Finance income \\
\hline 8 & Finance costs \\
\hline 9 & Profit before taxation \\
\hline 10 & Taxation \\
\hline 11 & Profit from continuing operations \\
\hline 12 & Profit attributed to equity holders \\
\hline 13 & Profit attributed to minority interests \\
\hline 14 & Earnings per share - basic and diluted \\
\hline 15 & Dividend per share \\
\hline \multicolumn{2}{|r|}{ Statement of recognised gains and losses } \\
\hline 16 & $\begin{array}{l}\text { Income recognised directly in equity, e.g. foreign currency translations, goodwill amortisation, fair value } \\
\text { gains and losses on tangible assets and financial instruments, etc }\end{array}$ \\
\hline 17 & $\begin{array}{l}\text { Loss recognised directly in equity, e.g. foreign currency translations, goodwill amortisation, fair value } \\
\text { gains and losses on tangible assets and financial instruments, etc }\end{array}$ \\
\hline 18 & Transactions with owners: share issues and redemptions, dividends and the purchase of treasury shares \\
\hline \multicolumn{2}{|r|}{ Balance sheet } \\
\hline 19 & Property, plant and equipment \\
\hline 20 & Investment property \\
\hline 21 & Investments in joint ventures and associates \\
\hline 22 & Deferred tax assets \\
\hline 23 & Intangible assets, e.g. goodwill \\
\hline 24 & Non-current financial assets, e.g. derivatives \\
\hline 25 & Inventories \\
\hline 26 & Current financial assets, e.g. derivatives \\
\hline 27 & Trade and other receivables \\
\hline 28 & Current tax assets \\
\hline 29 & Cash and cash equivalents \\
\hline 30 & Current financial liabilities, e.g. overdraft and derivatives \\
\hline 31 & Trade and other payables \\
\hline 32 & Current tax liabilities \\
\hline 33 & Non current financial liabilities, e.g. derivatives, mortgages, vehicle financing \\
\hline 34 & Retirement benefit obligations, e.g. pensions \\
\hline 35 & Deferred tax liabilities \\
\hline 36 & Provisions \\
\hline 37 & Minority interest in equity \\
\hline 38 & Issued capital \\
\hline 39 & Share premium \\
\hline 40 & Other reserves \\
\hline 41 & Profit and loss \\
\hline \multicolumn{2}{|c|}{ Cash flow statement } \\
\hline 42 & Cash flow from operating activities \\
\hline 43 & Cash flow from investment activities \\
\hline 44 & Cash flow from financing activities \\
\hline
\end{tabular}




\begin{tabular}{|c|c|c|c|c|c|c|c|c|c|}
\hline Variables $^{1}$ & Mean & Std dev & Median & $25 \%$ & $75 \%$ & Min & $\operatorname{Max}$ & Skewness & Kurtosis \\
\hline \multicolumn{10}{|l|}{ Extent and Focus of SNC } \\
\hline Overall supplementary narrative commentary & .302 & .0782 & .310 & .250 & .360 & .050 & .530 & -.167 & .223 \\
\hline $\begin{array}{l}\text { Income statement supplementary narrative } \\
\text { commentary }\end{array}$ & .423 & .1079 & .400 & .330 & .4700 & .070 & .730 & -.038 & 1.037 \\
\hline $\begin{array}{l}\text { Balance sheet supplementary narrative } \\
\text { commentary }\end{array}$ & .201 & .0856 & .220 & .130 & .260 & .040 & .430 & .253 & -.071 \\
\hline Supplementary narrative commentary focus & 2.659 & 1.9448 & 2.136 & 1.538 & 3.077 & .765 & 15.000 & 3.227 & 13.359 \\
\hline \multicolumn{10}{|l|}{ Board structure variables } \\
\hline Board size & 9.192 & 2.0911 & 9.000 & 8.000 & 10.000 & 5.000 & 20.000 & 1.375 & 4.173 \\
\hline Proportion of non-executive directors & .560 & .1010 & .560 & .560 & 630 & .300 & .833 & -.105 & -.266 \\
\hline Audit committee independence & .810 & .3497 & 1.000 & .750 & 1.000 & .000 & 1.000 & -1.557 & .782 \\
\hline Audit committee financial expertise & .380 & .1886 & .330 & .250 & .500 & .000 & 1.000 & 1.198 & 1.909 \\
\hline \multicolumn{10}{|l|}{ Control Variables } \\
\hline Company size (Market cap) (£’Million) & 1048.918 & 581.1937 & 884.500 & 560.180 & 1479.010 & 178.450 & 2547.980 & .775 & -.434 \\
\hline Analyst following & 5.521 & 2.8024 & 5.000 & 4.000 & 7.000 & .000 & 14.000 & .186 & -.131 \\
\hline Gearing & 1.066 & 1.1771 & .760 & .350 & 1.450 & .000 & 8.690 & 3.547 & 17.992 \\
\hline Profitability & .154 & .2495 & .130 & .060 & .200 & -1.420 & 2.080 & 1.842 & 31.318 \\
\hline Liquidity & 1.577 & 3.6209 & 1.010 & .720 & 1.350 & .150 & 44.990 & 10.644 & 126.253 \\
\hline Company age (Years of listing) & 20.665 & 18.5909 & 13.000 & 6.000 & 34.000 & .000 & 70.000 & 1.009 & .149 \\
\hline
\end{tabular}

${ }^{1}$ All variables are defined in Table 1. 


\begin{tabular}{|c|c|c|c|c|c|c|c|c|c|c|c|c|c|}
\hline \multicolumn{2}{|c|}{ Variable $^{1}$} & 1. & 2. & 3. & 4. & 5 . & 6. & 7. & 8. & 9. & 10. & 11. & 12. \\
\hline 1. & $\begin{array}{l}\text { Overall supplementary } \\
\text { narrative Commentary }\end{array}$ & 1.000 & & & & & & & & & & & \\
\hline 2. & $\begin{array}{l}\text { Supplementary narrative } \\
\text { commentary focus }\end{array}$ & $-.359 * * *$ & 1.000 & & & & & & & & & & \\
\hline 3. & Board size & $-.140 *$ & .012 & 1.000 & & & & & & & & & \\
\hline 4. & $\begin{array}{l}\text { Proportion of non-executive } \\
\text { directors }\end{array}$ & .012 & .069 & -.004 & 1.000 & & & & & & & & \\
\hline 5 . & $\begin{array}{l}\text { Audit committee } \\
\text { Independence }\end{array}$ & $.332 * * *$ & $-.159 * *$ & .065 & .065 & 1.000 & & & & & & & \\
\hline 6. & $\begin{array}{l}\text { Audit committee financial } \\
\text { expertise }\end{array}$ & $.232 * * *$ & $-.138 *$ & -.105 & $-.147 *$ & .106 & 1.000 & & & & & & \\
\hline 7. & Company size & $.308 * * *$ & $-.232 * * *$ & .050 & .049 & $.200 * * *$ & .028 & 1.000 & & & & & \\
\hline 8. & Analyst following & $.363 * * *$ & $.427 * * *$ & .007 & -.010 & $.237 * * *$ & $.150 *$ & $.240 * * *$ & 1.000 & & & & \\
\hline 9. & Gearing & $.238 * * *$ & $-.141 *$ & .013 & .038 & $.257 * * *$ & $.131 *$ & .080 & .106 & 1.000 & & & \\
\hline 10 . & Profitability & .033 & .015 & -.005 & .010 & -.028 & .087 & -.056 & .047 & -.099 & 1.000 & & \\
\hline 11. & Liquidity & $-.129 *$ & -.071 & .009 & -.048 & $-.167 * *$ & -.065 & -.012 & $-.163 * *$ & $-.137 *$ & -.071 & 1.000 & \\
\hline 12. & Company age & $.310 * * *$ & $-.177 * *$ & -.054 & -.044 & .021 & .025 & .112 & $.218 * * *$ & .014 & -.078 & -.118 & 1.000 \\
\hline
\end{tabular}

${ }^{1}$ All variables are defined in Table 1

***. Correlation is significant at the $1 \%$ level or better

**.Correlation is significant at the $5 \%$ level or better

*.Correlation is significant at the $10 \%$ level or better 


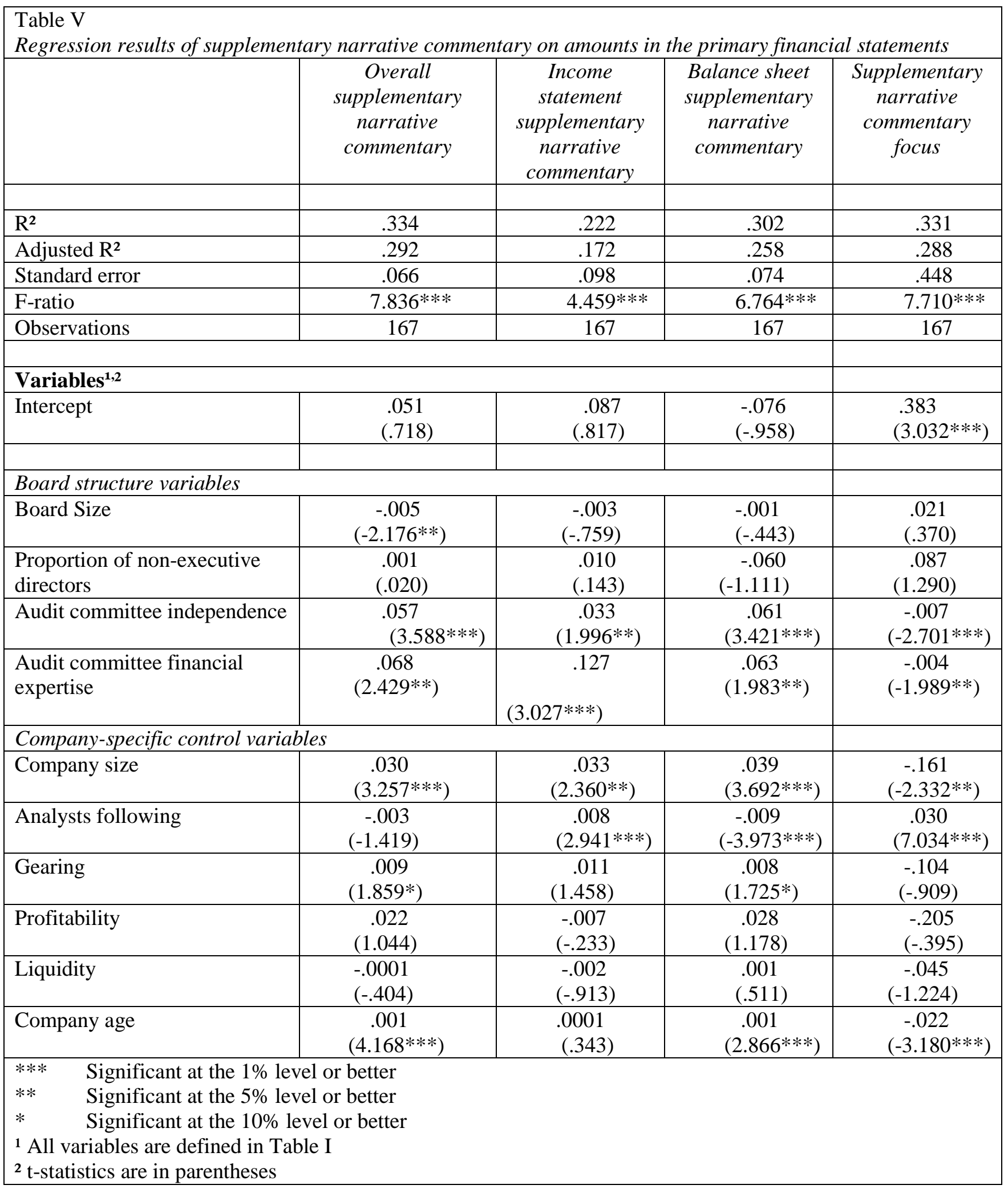

